\title{
大韓民国に使いして
}

$\begin{array}{lllll}\text { 語る人 } & \text { 安 } & \text { 䉂 } & \text { 豊 } & \text { 缐* } \\ \text { 聞く人 } & \text { 金 } & \text { 森 } & & \text { 隆*** } \\ & \text { 山 } & \text { 下 } & & \text { 寬*** }\end{array}$

年の瀬もせをる昭和 37 年 12 月 26 日午後 3 時半方ら約 1 䊁間にわたり真京・八重洲口，鉄鋼ビルの小野田せメント株式 会社東京支社で，安藤社長ほじぬ金森課長，山下氏らが，公私 ともに多忙な中学わざわざ窯業協会 4000 有余の会員のために， 躍動しつつ的る韓国の現状について聞き，語って戴いた。韓国 は日本の最む近い隣国であるにもかかわらず国交さえもいまだ 正常化せず，近く会馀が妥結されようとしている折柄，韓国定 改あて認識するためにぜひ一㜔ざんたい。

この原稿の整理については，金菻課長にひとかたなら放情 渮になった。話して和礼申上げます。

(富田)

金森 日韓国交の正常化，経済協力の推進といった 問題の中で，今般䅐善使節あるいは経済視察団の団長と して2回にわたり訪韓され，現実の姿な御覽になったわ けですが，安藤さんには，かつて約 20 年にわたる，あ ららでの御体験もお゙りのてとですので, 感慨も一しお と存じますが，本日は産業経済はもとより政治，軍專， 教育，民生等について広くお話を伺いたいと存じます。 まず，目的，御日程などについておきかせ願えませんで しょうか。

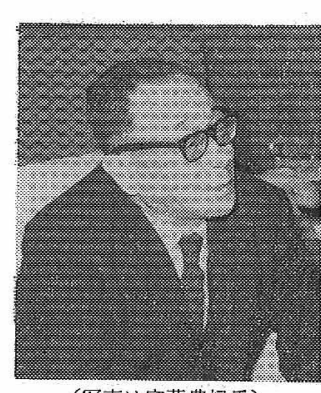

安藤 第 1 回目の訪韓は咋 年 9 月中旬に約 1 週間, 経団連 の植村さん等：行 7 名で，いわ ば good will mission として, 国情一般飞ついて，第 2 回目は 12 月の上中自纪引て 10 日間 会社，銀行関係の代表者 33 名 石油関係を除いて，注とんどの 産業界を網羅した訪韓経済視察 団として京城，板門店，仁川，釜山，蔚山，大邱，三陟 等犮回りました。

金森大変な歓迎を高受けになったそうですが，い かがでしたが，御印象は。

\section{昔とは大変な変り上う, 人々も生気発らつ}

安藤草とは大変な変わりようですな，都市等も極 わて清潔ですし，働く人達の服装も小ざっぱりとして， 活き活きしています。

*小野田セメント株式会社取締役社長

**通商産業省工業技術院繊維化学規格課長

****通商産業省軽工業局案業建材課

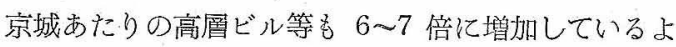
うに見受けられました。とにかく9月のときよりを，よ り一層強い印象范受けました。またあちらの人達か非常 に喜んでくれ䊩したし，日本語等も 9 月のときより 10 倍も使われているように感しられました。

金森南北の势力分布といったものについて……

安藤人口からいえば北伤が900 万人，韓国か 2600 万人ですが，㗢き盛りの人進か韓国の方へ逃げ远んで来 ていますから，实質的仙 $80 \%$ ○人間方湳にいるとい えましょう。軍搼は 60 万，自由傮営では 3 番目位の強 大な兵力です。しかもとれを戦時状態で持っているので すから大变なととです，日本の人口に延恬せば 250 万位 の軍隌を持ってるのと同じで，防共の役割を韓国ぶやっ ているわけですからその負担る大変なものがありましょ う.しかし逆に北鮮のう万 900 万の人日で 60 万の簐像 と対峙しなければならないのですから，むしろ困るのは 向うの方かる知れません. 少々位電力や無煙炭があると いってもですよね.

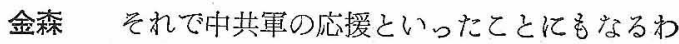
けですね。ところで、今の朴政稚についての評価はいか がですか。

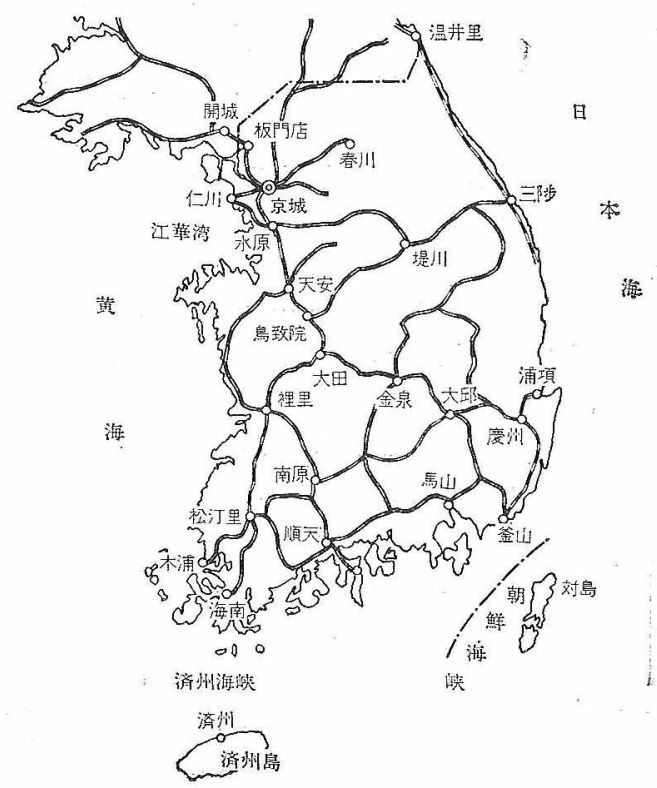




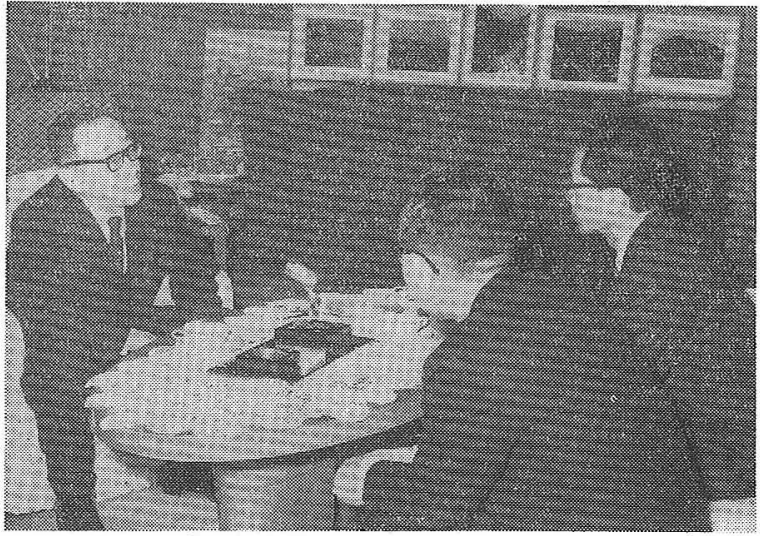

左から安藤社長，山下，金䅨の西氏

\section{まるでトロイ戦争}

安藤 謙虚に全力をあげて再建に当っているので内 外の信頼も大きく, 安定しているようです. 軍事政権と いっても8人は再度の人です，皆若くて，大部分の人が 40 才台で, 朝早くから夜叔そくまで卒先して働いてい ます。そして間違いは值ちに改めるといった謙虚さか祵 民の精神的な支持起得ている原因でしょう㸚。李，張政 㭚のときは窗敗もあり，威張っていましたからる。るれれ から 12 月の 17 日が改憲の投票日でしたが，86\%の 投票率，京城のような都市でも $78 \%$ で支持 $82 \%$ 反 対 $12 \%$ といった結果が出ています。

とにかく，との前, 南北動乱のときそ, 非常にまあ共 産側はひどいととをしている。まるでその昔のトロイ戦 争といったような残虛なととをやっていますよ，その有 椂は京城の士官学校の講堂に $10 \mathrm{~m}$ もある大きな油絵に なってかけてあります。

当時士官学校の生徒は 530 人わったといいますが，全 員が戦死して学校学守った。一人も逃げるものがいな い。まあとんなととは世界にすないと思います。学校と してはね。

金樊 日本の戦陣訓が向うで.......

安藤にそうです向うで生きたわけです。岢ちらでも そう言ってるんですよ。日本の良いとじろは戦陣訓，そ れとアメりカのサイエンス……テュラルサイエンスで

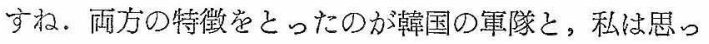
てい等守.

金森 そういう点でも，出話を极聞きしないとわ

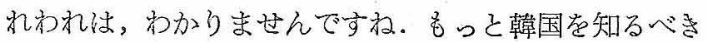
ですね.

安藤 その辺一番わからないんじゃないでしょうか

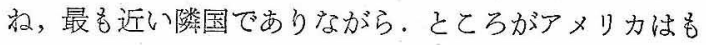
ちろんドイツにしてもデンマークにしても，イギリス， フランスあるいはイタリーにしても，一足先俍く見と

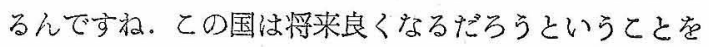

見抜いてるんです、だから最近新軍事政権になってから 水, 10 年, 12 年といった長い借款, それがまあ1億何 干万となってるんです.むうん政府の補瀕でもあるんで しょうけれど，いい子思うから政府も保証するわけで， 各国とも韓国を信用する状態になった。昔とは大変な違 いですね.

\section{清潔な街，昅殼も搭てられぬほど}

\section{金森街の有样などはいかがですか。}

安藤京城など治安が非常に良く，晚の 11 時頃で も女の 1 人歩きも出来るし，日本から行ったわれわれの 団員でも，朝の 5 時半，てれは日本なら 4 時半頃に当り ますが，てんな暗いうちでも 1 人で安心して散歩も出来 るほど治安はしっかりしてます，交通規則を良く守る， てれは当然なととですが，日本，特に今の東京の有様か ら見れぱ，それは非常に良く守られています。これは軍 事政権の前から守られているそうですが，やはり，ヨ夕 モンなんていらのはおらんのですから，自然良くなるん でしょうな。

向うの復興の具合はどうかというと，京城あたりの市

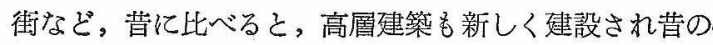
数倍, 人によっては 10 倍も増光ているという人もいる 位です。道路も広く，立派になって，それから清慗なと とは，警くばかりで... :タバコの吸殼を捨てるのに，ど こへ捨てようかなと，いう感じがする程です．日本とは 大部違います。道を歩く人の服装を見ても，なかなか， 小ざっぱりしているんですよ。ぜいたくじゃありません が。清㳊感のある必要にして充分な服装です，てれが理 想的だと思いますね。

金森経済の面ではアメリカの嗳助とか，借款と か，負債的な資金が大きな役割をしていると思われます si..........

安藤 それはそうです。何分にも60万の兵隊を戦 時状態で持ってるんですから大変なととです，60 万の 軍隊を養うとい壳ば，その背後には平常でも 2 倍, 戦時 なら 5 倍もの人が要りますからててんな点でるどうして

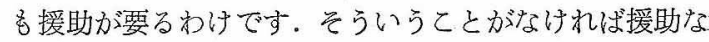
んか要りません．9月の時には第一線まで行って見たん， ですがね，すわとい壳ば1分以内に思う妈へ大施の弾が 打ち込就るよになっています。約 $200 \mathrm{~km}$ の戦線を優 㛀を保ちながら維持しなければならない，前線に配置し ている数はちょっと言われんでしょうが，ほとんど半分 位はそこにいるわけでしょうから，大変ですよね。

\section{電気亡機械のがたりのような技術教育}

金箖教育関係はいかがですか，戦前は大学なども 京城1つでしたが...... 
安藤 今は大学は 62 かあるんですよ, しかも非常 记立派でしてね，まあ，5階 6 階建の建物が並んでいる ような大学が方々にあります。

金森 学制は日本と同じですか….....

安藤 $6 \cdot 3 \cdot 3 \cdot 4$ で, 同じです, 62 かの大学に学 ぶ学生数は 10 万以上 12 万人とかいってました。 それ よりも水，2 年半の教育を受けて陸軍なん猄；軍隊から 除隊して出て来る人というのは，てれはまあ，機械と電 気のかたまりみたようなものですよ，士官学校あたりで ま半分は技術教育です.

金森 2年半というのは士官学校ですか？

安藤い, 认兵役です. 大体 2 年 2 力月から 2 年半 位になるそうです。ものよって違うそうですが，大体 機械と電気の教育を専門的に受けており，そういうもの が年々 24 25 万も出るわけですから，産業予備軍とし てはね，大変なものでず，どんな仕事にもパッと直ぐに も役立ちます．兵役は徽兵制ですが，てれは大学を出て も必らず行かねばならん，行かなきゃ，世の中に出るて とならん，今度でも大概のととはいいけれど，徽兵を忌 避したものは議員になっちゃならんと…..., 議員に立候 補できないというととか湽法の中にあるようです：ま あ，一生懸命やっとりますね：そんなわけで，何か仕事 をやるときには非常に具合がよい，たと光ば日産自動車 が向うで組立工場を作っとるが，極めてうまく行ってま す.それと……てれは男の方ですが，女子でも韓国では 非常に手先が器用で，たとえば日本でじばりを作ります ね，てれは日本では普通まあ 1 寸に 11 針ですが韓国の 人なら 16 もじります。ですからら昔は細かいしばりは 韓国專門で，日本では出来なかったんです，そういうわ けで近頃細かいしばりは日本にはないでしょう。そのよ うに器用さという点は男の方にも同じように伝わってい るわけですよ。

山下それはちりめん等のしばりのてとですね，今 晌うで衣料・瀻維関係はどんな具合ですか.

安藤、製品としては全部自給自足です.もちろん綿 花も羊毛も，原料はありませんけどね，スフあたりは糸 あるいはその前の原織を輸入してますが，その後は自給 自足です。そういう紡續工場も，毛織工場も見ました が, 大邱の毛織工場など全織の 3 割 5 分位のものを飔っ とるんですがトッピングから織物まで最後までやってお り，日本の第一流工場と此べてもひけをとりませんな. 製品も，なかなか立派なものが出来てます，学働環境も よく，女工さん達もきちんとしてますし，厚生施設も非 常に良く，寄宿舎なども立派で，美化しすぎる位にして います。また。ナイロンなどの新しいものも，今，中間 物を輸入して糸にするとてろからやろうとしています。

山下 そういうのは日本で援助しているわけです 补.
安藤 “東洋レーヨンが援助する形のようです，デュ ポンとも話をして…..しがし東レの方が近いので日本か らというととです。そういう加工のとてろは韓国で十分 そやってます。

\section{1 人当りの収入は日本の 5 分の 1 , 鉱工業の水準も低いが}

金森経済規模と申しますか，たとえば国家予算の 規模などはどの位のものでしょうか…....

安藤 そりゃ，まあ, 日本の 10 分の 1 よりずーと 以下でしょうね。

大体 1 人当りの収入が 75 ドル位ですから, 日本の 400 ドルに比べ 5 分の 1 か 6 分の 1 程度ですな，しかし 向うは物価が安け，米は 8 割位ですが他の物は 2 分の 1 から 3 分の 1 位でしょうね, 従って日本からいえば半分 程度の生活費ではありますまいか。

経済の水準は，まあ日本の半分位だと思ってよいでし ょう。しかし，皆が良く働しうという意気がありますか ら，そこに，底力があるわけでずよね。

金森産業実勢と申しますか, 朝鮮銀行で出してる 統計を見ましても鉱工業生産などは非常に低いようです si......

安藤 それは,もともと南朝鮮は鉱工業が無かった 処です, 御承知のとおり, 電気が無い.......えのかわり農 水産と軽工業が主力でしたからね，それにひきか光北は 電気もあれば鉱産資源もあり，いわゆるへビーインダス トリービゃないですか，ですから南は鉱工業というと非 常に少なくなるわけです。しかし無煙炭などは，われわ れの時には 80 万トン位でしたが今は 600 万トン出てい ます.

金森 電力もずい分少いようですが…....ネルギー 源について…..

安藤 今ね，11月に 37 万キロにはじめてなったと 言っておりましたが，てれが戦後最大だそうです．38年 の末までには 11 万キロ増えると言っております，てれ は出力ですが，ほとんどしょっちゅう回していますか ら，まあ 7000 時間位はがけてもいい位の運転をしとる でしょう。しかし電力は日本とは比較にもなりません， 100 分の 1 位じゃありませんか. 火力が 6 割位で, 建設 中のは皆火力です，とにかく無煙炭が安くキロカロリ一 当り 48 銭という值段ですからね，日本は70銭ですよ。

まあこの無煙炭の增産なはかっているんですが，まだ 非常に幼稚なやり方をやってます，ほとんど選鉱はやっ ておらんようですね：選鉱機を使って本気でやればぐっ と良くなるでしょう。それから新しい炭坑も大部見つか ってます，まあ10 何億トンとあるようですから，将来 良くなるでしょうな，有煙炭はほとんど出ませんから国 外に頼るほかありますまい。 


\section{物価は安い，洋服は日本の3 分の 1}

金森 值段のことが出ましたが為替レートは，過去 そ捛いて次第に悪くなってるようですが，現在ドルとの レイトはどの位なのですか？

安藤 130 ウォンが 1 ドルです。で 1 ウォンは丁度日

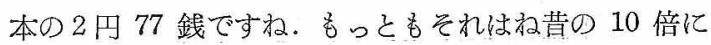
したんです，昔ファーンといってたのをウォンにしたわ けで, まあ 10 分の 1 というととですね. 前, ず一っと インフレがあったわけです，つまり李政権の終り頃から 張勉政権になった，あの時分が非常に悪いですね，わた くしも向うで, 大蔵次官……アメリカの人に会ったので

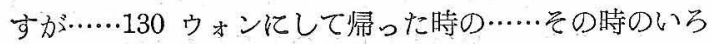
いろの話を聞いたのですが，今もそのレイトは続いてい ます. 今国内物価はインフレになっておりません，たと 壳ば洋服はですね，日本の 3 分の 1 ですよ，ての間てち らから行った会社の社長が，向うで造った布地で向うで あつら光た服がなんと 9800 円ですよ，それはずーっと 着て州ってますが立派なるんですわ.

\section{金森 鉄鋼関係はいかがですが?}

安藤、こりゃもう，ほとんどゼロです，仁川に昔の 理研金属というのがありましたが，てれが今鋼塊年産 5 万トン, 1966 年には 9 万トンになる見込みだそうです が高炉は無く，皆平炻から先の仕事です、かなり動かし ておりますがそそりゃ，鉱工業から見れば，微々たるも のです.

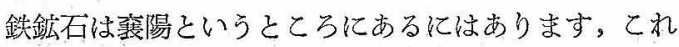
はまあ年に 20〜30 万トン位掘れる。韓国の今の 35 万 トン位の訫画まあ，それをだんだん大きくしていけ ば，それで数年間はもつでしょう，しかし結局は鉄鉱石 は輸入しませんてとにはすまんでしょうな。

\section{セメントは 2 工場, キロカロリー当 り 48 鐵の石崖の強み}

山下 セメント，板ガラス等䉕業関係は，どんな具 合でしょうか？

安藤 セメントは今 2 工場あります，1つは三陟， とては昔わたくし共がやっていた工場, 方う 1 つ聞慶 で，莦，用意をしとった工場です，三陟は当時レポール 学1本据光ておったんですが，何分昭和 17 年の頃で， 村料は無し，機倳も悪くってね……筧自身はよでざんす けどギヤ一等他のものが悪く困っとったのですが，今 はすっかり良くしまして，2本になっております，操 業状沇も良く年に 35 36 万トンとなかなか上手に運転 してます。

山下 2 基とすレポールですか，それから然料㹥無煙 炭でしょうね。

安藤 レポールで， 580 トンと 480 トンです。燃
料は無煙炭が 8 割, 有煙炭が 2 割のとてろでやってます 小, 大体が 96 97 万キロカロリーでやってます, 品質

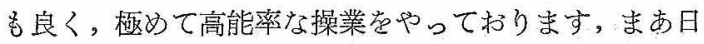
本待って来ても，何でしょう，特殊のレポールの平均 よりも，向うの方がいい位のとと党やっております。而 火煉瓦は，南でも原料が多いですから自給してます. 石 灰石は，ほとんぞ無限……1 億，2 億とありますから問 題ありません。

山下 聞慶の方は……

安藤 ここは今，スミスのロングキルンです，120 m. $3.3 \mathrm{~m}$ でしたかな，てれが 3 本あります，まあ， あまりロングではない。従って年に約 40 万トン位でし ょうな，1日，400 トン位，3基で1,200トンといった とてろでしょう。とれも非常に清潔な工場で，きしっと しています。ただ原料は石灰石ばかりでやってます，粘 土分は自然と石灰石の中にある......., 一部 3 分の1 位は フローテイションをやり品位を上げて，一緒にして湿式 でやってます。ててれはまあ常識的な方法ですがただ゙社 宅なんかる大变立派で，270〜280 軒もの社宅があり， すべての厚生施設はいたれりつくせりです，やはり 48 銭の石炭を使ってますからね.

そとは同時に自家発電もしております，自家発電が 8,000 キ口当ある，てれが何と安くって极，なにしろ石 炭か洝いもんですから齐，2月80 銭位でやっておりま す.

\section{板ガラス工場も自力で設計，技師長 は 37 おの若さ}

\section{山下 板ガラスはいかがですか？}

安藤てとれは仁川にね，3 年位前汃ら始めたんで す。わたくしも見たんですが，フルコールでず. 引上げ

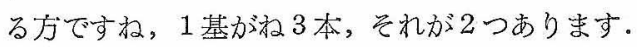

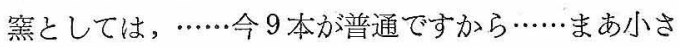
いものですが、なかなか良く運転してます。その内の1 基は韓国の技術者達が設計をして新しく造ったものです が，今年 (37 年) 出来て 11 月に火を入れて，12 月に

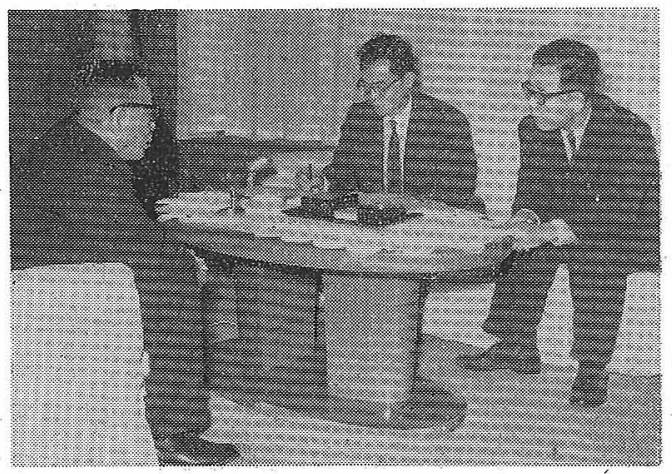

左から安藤社長, 金森, 山下の両氏 
はちょんと立派に運転してました。品物はちょっと胃た

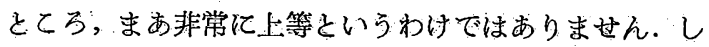
かしガラスはやっかいですから齐，だからあの位にてな すというととは技術優秀とみなければなりますまい。と

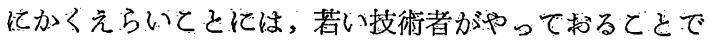
す，てての技師長は 37 才という若さです。

セメント工場でも，やはり，40 そてそての人が場 長，てれはわたしどものときに，て鸟中なかなか出来る 人だと言ってたんですがね。なかな良くゃ曰てます。 規律も正しいし，掃除は行きとどいてますし，感心です な.

\section{金森：労働時間なんか就どうですか？}

安藤８８時間です，学㗢条件は処代もよりますが， 窝業関係は比較的良い方でしょう称。貨金虫まあ日本の 半分位じゃないでしょうか，し为し物が安いですから， 従って案業関係では，ほぼ日本と同じ位な暮うしをして ます。

金森＼cjkstart経済統制といってもどの程度にやってるので すか?

安藤 普通の産業は全部民間にまかすつもりでいる と，いっていますたただね，実際問題としては外貨がな いんですからね……民間で勝手に持って来るわけにはい かんですよね. 結局は政府が保証を与光るとか，口を出 さんととにはね，たと党ば綿花の輸入量で，その，紡績 の統制が出て来るといった意味の統制は自然に出来てき ますよね，まあ，財政金融面での統制は，援助資金の面 からも当然行なわれておりますりしかし，原則的には是 間にまかせるというととが念願であるとりうととを軍部 の将校の長官といった人々が全部そういってます。

\section{物資の統制む原則的にはやてない}

金森燃料とか，セメント，板ガラスといっだ物資 の統制惊やっていないのですか？

安藤、てれはやっておりません。しがしセメントな ぞ，官需は先にやれといったととにはなるんですが，民 間の場合，七メントが足りませんから、标常汒上がる おそれがあるというので，两る程度輸入もしなさいとい うようなととになっとる。要は外価为是らないんですか ら，今としちゃ称，てりゃ，まお，ちょうど，昭和 28 年が終戦ですな, 向うは，……間南北動乱……え万 いとをやっとったですからね，それで120万もの人が 死んだんですから，しかも，ほ之んど全部媌けてしまっ たんですからね，その荒廃の状沇性日本の場合より，う んとひどかったのですから，そんな点から見れば，今， てれだけやっておれば；まあ相当いいとしらではないで しょうか.

金森一経済，技術の面で，日本に対し，今，何を最 も望んでおりますか?
安藤 间らは，その何でも望んでおる……大げさに 言党ばね，日本のものは安くて品物がよろしいと，それ から日本人なら言葉も通ずるし，近いから修理もすぐ出 来る…ㄷといらたてとはよくわ加ているのですが， ただ日本で图るのは，延べ払いが出来ない、現金が向う は無いれですから，長い借款にするより他场を入れる 方法がない，従ってセメント機械あたりにしても日本 で，神裴鎆がレポールなんかをやったときには，向う が 600 万ドルで日本は 450 万ドルでしたが，そんなに安 いれですよ。しかし580万ドルでも向らへ入れる，何故 かと言うと，金隹無い、日本は現金，あるいはそれに近 いととを言う。それで結局はドイツのものを入れました が放，向うの人は残念がっているんですよ。

日本としては，国交正常化でもやってです权，そうい うととに応じ得るようにならなければ，日本から物を持 って行くといっても，特に安く，日本のが特に良いとい った特殊の場合以外，てれ性事実上ものになりません わ. 今度ね, ああして 2 億, 3 億合計 5 億ドルといった 話もありましたが权，まあ，ああいうようなととに，そ の内に含めるとかあるいはもう少し進んで, そのほかに 出すとか，というととと技術が一緒でなければ意味ない ですね.

金森 そうですね，いくら何でも，日本の産業とし て，只奉公は出来ませんでしょうからね。

\section{長い目から見れば向うが栄えること は目本の栄元る道}

安藤 只奉公は勿論出来ないですけれど，長い目から

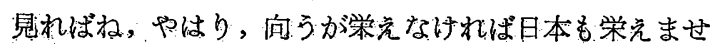
んよ.とりゃ少し大きく言光ば EEC をやらなきなら ん. 向らの大も，扬に EECのようなととにならにゃ ならんのですが，そういうとき韓国はどういう地位でし ようか，というととを向うの新聞記者が私に言っとりま したがわたしもね，そり何といっても韓国は，東南ア ジア何拾ケ国の内で一番教育の䅝度も高く, 普及もしと る処です，日本とほほ同じ程度位までなっとる，従って そういう国がかかる役割をすべきかはおのずから明ら かじゃないか，というととを話しましたが，喜んでおり ました:

そりゃ,フィりッピン,インドネシャ,多仙たりと は違いますよ，…ㄷててからもう，ただ伸びるだけの 国ですからね，てれからの大きな市場なんですよね，と に汃頭もあり，やらうという考光もあり，それ加ら体 力もあるといら人が 2,600 万人そらっているんですから ね.まあ,て执が順調化伸びてもらうということは，て りゃ日本としても非常に夫切なととです.

金森向うの 5 ケ年計画の最重点は何処にありまし 上うか？ 


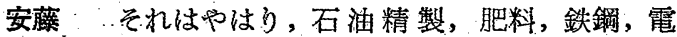
力, それから石炭, セメントといった重化学工策です な.

発電というても 100 万キロにしようというんですが， まあ青から見れば少ないもんですか。鉄にしても 35 万 トンでてれる小さな話です，肥料が 20 万トンというん です。康素として，てれはやや大きい方でしょう．石 油，娄ちろん油田はありまんが，ての3万バーレル： これもたいしたてとじない, 従って，やろうというそ の重工業が，なんだそんな大きなととをやって，とても 出来ないというこっちゃないんですよ。

金森．...最後にですね，御体験上，日本国民とか，日 本政府に娰する要望とでも申しますが，それを一言で吉 ๖ていただくと，どういうことになりましょうか？

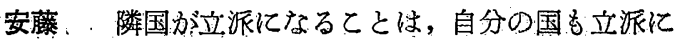
なるととだと思わなきいかん，従って，親切て利，そ のい施并の国が大きくなるんだというつもりで、， 温い心でただ毫けるというととばかりじゃいかん，向 うに多少でも力になってあげるんだという気でもってや
らねばいかん，従って间うから来る人あたりにまよほど 親切にして，お互の聞の交流を盛んにする必要がありま Uょ

まあ，精神的とも; 技術的にも，物質的にも，資金的 にも親切にやっていとうというととが非常に大切なとと です.磷国でけんかしていたんでは話になりませんです わ.

そに加人，自由主義の㫿一の国だと，一番近いね，乙 れを考えなきいかんですよ，日本が共虐党になるつも りならてれはまた何をか言わんやですがね。

半島の 7 割 5 分が韓国で, しかもそれが自由主義陣営 であるとと……，共産国之相接しておるために大変な金 も使った，従りて経済的にも困るだろうというてとは当 然孝えられることですから，まあてれは政治的なととに なりますけれど，と言って，政治と経済は必ずしも別じ やありませんからね.そういうととを考光ればまず, 韓 国と手を握るべきだとわたしは思います。

金森 どうもお忙しいとてろをいろいる有難うござ いました。

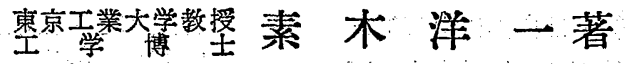

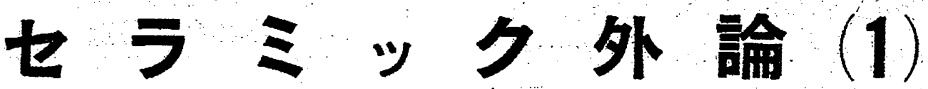

B 5 判 8 ポイント二段組 137 ペーシ 定価 500 円 $\mathbf{T} 60$ 円

本書怡会誌連載中のものであるが, 完結をみるまでにな拈 2 年くらいの時間を要するので, 取りあえす第 1 章为ら第 6 章までをまとめて印刷し，読者の要望に応えることになった。内容 は下記の通りであるが, 既刊の窝業関係の書籍と異なり製造に直結した問題を取り上げて平易 に解説してあるので, 新入社員の教育や工業高校の教材として最適のものである。

\section{内 容}

緒 合

第 1 章 原料選択には如何なる試験を行な うぺきが

1. 普通製品に用いられるものに刘する試験項

目 2. 特殊製品に用いられるものの対する試 験項目 3. British Ceramic Research As. sociation で行なわれた研究の概要 4. T.V. A.の陶磁器研究所で行なわれた研究の概要

\section{第 2 寞 粘士類の結晶構造}

1. カオリン鉱物 2. ハロイサイト. 3. パ イロフィライト 4. モンモリロナイト 5. 粘土状零母 6 . 滑石

第 3 亲 案業原料としての粘土類の基本の 性澌。

1. 附随物質 2. 示甠分析 3. 化学分析值 発行所 祬团 熟
目 次 少ら鉣物組成を求める方法 4. 粘土の鉱物組 成之物理性との関係 5. 粘土の塩基置換性と 飽和粘土の特性

\section{第 4 章 粘土一水系}

1.コロイド化学的性質 2. 泥浆の粘性 3. 練り土の可晆性 4. 練り土の成形能 5. 練 り土のおし出し能 6. 土練機に関する基本問 題 1. 練り土の粘弾性 8. 可塑性の測定方 法

第5 章 粉 砕

1. 粉砕の理論 2. 粉砕機の効率 3. 粉砕 機の種類

\section{第 6 章 分離亡粒度測定}

1. 固体一固体系の分離 2 . 粒度分析 3. 固体一液体系の分離

策協 会

東京都港区芝西久保桜川町 7 番地 電話 (591) 2031-2032 振替口座 東京 21133 番 